DOI: http://dx.doi.org/10.12775/SE.2020.00040 Uniwersytet Gdański, kontakt: justyna.zysk@ug.edu.pl,

ORCID ID: 0000-0002-2856-4209

Sztuka Edycji 2/2020

ISSN 2084-7963 (print)

ISSN 2391-7903 (online)

s. 208-209

\section{Justyna Zyśk}

Wojenna

Warszawa

w obrazach popkultury

Popularyzowanie wiedzy o dziejach narodowych w taki sposób, aby stały się one bliskie współczesnym nastolatkom, zarówno pod względem intelektualnym, jak i emocjonalnym, nie jest łatwe. Warunek konieczny stanowi tutaj atrakcyjny przekaz, dzięki któremu suche fakty przemieniają się w żywe obrazy historii, zachęcające młodego odbiorcę do dalszych eksploracji. Wydaje się, że to zadanie może odpowiednio spełniać komiks historyczny, o czym przekonuje spora liczba opowieści z dymkami zawartych w aktualnej ofercie wydawniczej wielu instytucji państwowych zajmujących się edukacją historyczną, takich jak Instytut Pamięci Narodowej, Muzeum Historii Polski, Ambasada RP w Tokio, Muzeum II Wojny Światowej w Gdańsku czy Muzeum Powstania Warszawskiego ${ }^{1}$. Niedawno nakładem wydawnictwa ostatniej z wymienionych jednostek oraz Egmont Polska ukazał się trzeci już tom jednej z ciekawszych serii w tej kategorii, czyli Bradl Tobiasza Piątkowskiego (scenariusz) i Marka Oleksickiego (rysunki) ${ }^{2}$.

Komiks ten zwraca szczególną uwagę czytelnika wyborem tematu i sposobem przedstawienia go w kadrach. Opowiada bowiem o losach autentycznej postaci, Kazimierza Leskiego (1912-2000) - tytułowego Bradla, znanego także pod pseudonimami „37” czy „Leon Juchniewicz”, inżyniera-wynalazcy, uczestnika powstania warszawskiego, działacza polskich organizacji podziemnych, m.in. Muszkieterów, gdzie pełnił funkcję szefa komórki kontrwywiadu. Fascynująca biografia tego żołnierza Polskiego Państwa Podziemnego, opisana przez niego w książce Życie niewtaściwie urozmaicone ${ }^{3}$, posłużyła jednak twórcom komiksowej serii tylko jako inspiracja do zbudowania fikcyjnej fabuły. Ta ucieczka od weryzmu ma swoje źródło w ramach formalnych, jakie określają Bradla, czyli w rozwiązaniach zaczerpniętych z tradycji amerykańskich komiksów o bohaterach i klasycznych kryminałów noir. Rezultatem tego zabiegu jest pasjonująca opowieść szpiegowska osnuta na tle okupowanej Warszawy, której ponury nastrój doskonale oddaje estetyka rodem z gangsterskich filmów, świetnie uchwycona w rysunkach przez ciemne barwy, cienie, wyraźne kontrasty, ukośne linie podkreślające dynamiczną akcję.

Najnowszy tom, podobnie jak poprzednie, składa się z dwóch zeszytów z odrębnymi okładkami. W pierwszej noweli pt. Pōrando-kaiko poznajemy początki działalności wywiadowczej szefa Muszkieterów, Stefana Witkowskiego, w drugiej zaś pt. Qui pro quo błyskotliwy podstęp „Bradla”, wykorzystującego słabości hitlerowskiego urzędnika do zasilenia kasy konspiracyjnej organizacji. Obie fabuły wskazują na pewne przesunięcie akcentu w prezentowaniu losów głównego bohatera - w trzecim tomie twórcy odchodzą od ukazywania bezpośrednich zmagań z okupantem na rzecz zobrazowania intryg wywiadowczych i dyplomatycznych rozgrywek decydujących o przebiegu działań na froncie. W związku z tym obserwujemy postaci skupione na realizacji zadań często przyziemnych (dodajmy, że Leskiemu taki obrót spraw raczej się nie podoba), np. na zbieraniu funduszy na działalność wywiadowczą, zapewnieniu jednej z restauracji stołecznych dostępu do żywego inwentarza, wykonywaniu prac fizycznych podczas „kwarantanny” odbywanej na prowincji. Pozostawiając teatr wielkiej wojny w odległym the swych opowieści, autorzy starają się unikać patosu, a tym samym przybliżyć do czytelnika sylwetki bohaterów. Ci zaś nie są posągowi - przedstawiają się nie tylko jako waleczni żołnierze, lecz także jako indywidualności naznaczone wadami, mroczną przeszłością, których brawurowe akcje to często 
nie wynik zdolności strategicznych, a raczej chęci popisania się, dopięcia swego bądź po prostu przypadku. Leski, realizując zadania, bywa niefrasobliwy i zawadiacki, a gdy nadarza się okazja, jego zdaniem, do lepszego załatwienia sprawy, nagina otrzymane rozkazy. Można odnieść wrażenie, że działa w wywiadzie przede wszystkim dlatego, że lubi to zajęcie i jest w tym dobry, nie tylko z powodu wysokich pobudek. Zwłaszcza sposób przedstawienia go w drugim zeszycie omawianego tomu, jako przystojnego salonowca w eleganckim garniturze, działającego pod przykrywką na potrzeby akcji, nasuwa dość wyraźne skojarzenia z Bondem i można ów chwyt postrzegać jako udaną próbę wykreowania polskiej wersji tej postaci (lub też nawiązania do niej).

I tak oto w omawianym komiksie dokonuje się swoisty paradoks: twórcy, dążąc do zminimalizowania nastroju podniosłości, nadają bohaterowi „współczesne” oblicze, dzięki czemu odbiorcy łatwiej jest się z nim utożsamić. Zarazem jednak to „urealnienie” w połączeniu z motywami zaczerpniętymi z komiksów amerykańskich sprawia, że prawdziwa, historyczna postać nabywa cech fikcyjnej kreacji z powieści Iana Flaminga. Tą drogą więc bohaterowie Bradla wraz z wojenną Warszawą zostają wprowadzeni do świata popkulturowego. W nim zaś przestrzeń - główny, obok Leskiego, bohater tej serii - zostaje w pewnym stopniu zuniformizowana. W pierwszym rozdziale szybka akcja, przeplatana kilkoma wątkami, toczy się w Warszawie i Szwajcarii, jednak dopiero pod koniec tej noweli (liczącej 32 strony) na stronie 26 pojawia się pierwszy rysunek jednoznacznie wskazujący na trwającą wojnę. W drugim rozdziale ze względu na to, że fortel „Bradla” realizowany jest w salonie jednej z warszawskich kamienic, niemal cała fabuła przebiega we wnętrzu budynku, przez co znowu sceneria tu naszkicowana nie kojarzy się bezpośrednio z okupowaną stolicą. Zatarciu cech swoistych przestrzeni miejskiej czy też raczej dbaniu o to, by nie dominowały one w kadrach, sprzyja zastosowana konwencja czarnych kryminałów, a więc m.in. przedstawianie zaciemnionych miejsc, nielicznych znaczących detali, prowadzenie dynamicznej, wielowątkowej akcji, często zawieszanej dla zbudowania napięcia, co świadomie ma wprowadzać czytelnika w pewną dezorientację, zmuszać go do skupienia i prześledzenia wcześniejszych kadrów. Dlatego też można by zaryzykować twierdzenie, że bez przedmowy opisującej życiorys Leskiego i działalność polskiej konspiracji (autorstwa dr. Władysława Bułhaka) oraz fotografii z archiwum rodzinnego „Bradla” zamieszczonych na końcu tomu w niektórych epizodach tych opowieści czytelnik mógłby nie mieć pewności co do tego, gdzie dzieje się akcja i kim naprawdę jest tytułowy bohater.
Podsumowując, trzeba stwierdzić, że tom trzeci Bradla to doskonała lektura dla odbiorcy poszukującego w komiksach historycznych przede wszystkim rozrywki. Scenariusz i rysunki tworzą spójną, intrygującą całość, wzbogaconą o pewne walory edukacyjne dzięki temu, że fabuła jest osnuta na kanwie autentycznej biografii. Tym samym publikacja Piątkowskiego i Oleksickiego ma szansę trafić do szerokiego grona czytelników, obejmującego młodzież i dorosłych. Zastanawiające jest tylko, czy zaprezentowany tu sposób mówienia o drugiej wojnie światowej jest rzeczywiście popularyzowaniem wiedzy o niej, czy raczej stanowi przykład banalizowania historii za pomocą spetryfikowanych obrazów kultury masowej ${ }^{4}$. Wątpliwość ta jest o tyle zasadna, że podobny dysonans można odczuwać, czytając o efektownych, udanych akcjach „Bradla” przeprowadzonych w traumatycznej rzeczywistości okupowanej stolicy i nieuchronnie zbliżających się tragicznych wydarzeniach 1944 roku.

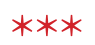

T. Piątkowski, M. Oleksicki, Bradl, t. 3: Pōrando-kaiko i Qui pro quo, Muzeum Powstania Warszawskiego, Egmont Polska, Warszawa 2018

'Zob. m.in. serie komiksów historycznych opublikowanych przez IPN Wojenna odyseja Antka Srebrnego 1939-1946 oraz Wilcze tropy. Muzeum Historii Polski wraz z IPN organizuje z kolei ogólnopolskie konkursy, skierowane do uczniów szkół podstawowych i ponadpodstawowych, na przedstawienie w komiksie epizodu z dziejów polskich. Prace laureatów są prezentowane na stronach internetowych instytucji partnerskich tego projektu. Muzeum II Wojny Światowej w Gdańsku za pośrednictwem takich komiksów, jak: Jachna, Katyń, Akcja Kopernik, Irena Sendlerowa i łyżeczka życia, upowszechnia wiedzę na temat ważnych postaci i wydarzeń z okresu drugiej wojny światowej. Komiksowa forma dobrze służy również promowaniu polskiej historii i kultury za granicą, o czym świadczy choćby cykl „Wielcy Polacy” wydawany przez Ambasadę RP w Tokio, który ukazuje sylwetki wybitnych rodaków.

${ }^{2}$ T. Piątkowski (scenariusz), M. Oleksicki (rysunki), Bradl, t. 3: Pōrando-kaiko i Qui pro quo, Warszawa 2018. Zob. dwa poprzednie tomy Bradla, t. 1: Dom pełen robaków i Zmartwychwstanie w Szpitalu Ujazdowskim, Warszawa 2017; t. 2: Jaskinia smoka i Diabeł w pudeł ku, Warszawa 2017.

${ }^{3} \mathrm{~K}$. Leski, Życie niewłaściwie urozmaicone. Wspomnienia oficera wywiadu i kontrwywiadu, t. 1-2, Gdańsk 2009.

${ }^{4}$ Zob. obszerne studium na ten temat w: J. Czaja, Historia Polski w komiksowych kadrach, Poznań 2010, s. 15-40. 